\title{
Production of dengue virus-like particles serotype-3 in silkworm larvae and their ability to elicit a humoral immune response in mice
}

\author{
Doddy Irawan Setyo Utomo' , Sabar Pambudi ${ }^{2}$, Fithriyah Sjatha ${ }^{3}$, Tatsuya Kato ${ }^{1,4}$ and Enoch Y. Park ${ }^{1,4^{*}}$ (i)
}

\begin{abstract}
To develop monovalent dengue virus-like particle for serotype 3 (DENV-LP/3), we prepared and expressed two structural polyprotein constructs using silkworm and Bm5 cells: DENV-3 Capsid-premembrane-envelope (DENV-3CprME) and premembrane-envelope (DENV-3prME). The expressed PA-tagged 3CprME and 3prME polypeptides were partially purified by PA-tag affinity chromatography and had molecular weights of 85 and $75 \mathrm{kDa}$, respectively. Expressed proteins were separately verified using the following primary antibodies: the anti-PA tag antibody, DENV premembrane polyclonal antibody, and DENV envelope polyclonal antibody. Transmission electron microscopy revealed that these DENV-3CprME and 3prME formed rough, spherical DENV-LPs (DENV-LP/3CprME and DENV-LP/3prME), respectively, with a diameter of 30-55 $\mathrm{nm}$. The heparin-binding assay demonstrated that these DENV-LPs contained the envelope protein domain III on their surfaces. Both DENV-LPs showed an affinity to sera from human dengue patients and immunized mice. Immunization of mice with DENV-LP/3prME significantly induced the level of antibodies compared with DENV-LP/3CprME. These results indicate that DENV-LP/3prME is suitable as a vaccine candidate compared with DENV-LP/3CprME.
\end{abstract}

Keywords: Dengue virus, Capsid, Premembrane, Envelope, Dengue virus-like particle, Silkworm

\section{Introduction}

Dengue virus (DENV) is a single-stranded RNA arbovirus that has caused a global epidemic, which is most prominent in tropical and subtropical regions of the Americas, Asia, Africa, and the Pacific Islands. The number of cases of dengue has been registered by the World Health Organization (WHO) since the 1950s, In 2016, the WHO estimated a global case rate of over 3.34 million cases a year, compared with a case rate of $<1000$ cases a year in the 1950 s. It was estimated that $\sim 390$ million DENV infections occur annually, while another study suggested that 3.9 billion people in 128 countries were at risk for DENV infection. Healthcare costs associated

\footnotetext{
*Correspondence: park.enoch@shizuoka.ac.jp

${ }^{1}$ Laboratory of Biotechnology, Graduate School of Science and Technology, Shizuoka University, 836 Ohya, Suruga-ku, Shizuoka 422-8529, Japan

Full list of author information is available at the end of the article
}

with dengue fever alone add up to approximately 8.9 billion US dollars per year worldwide. Among dengue cases worldwide, approximately $18 \%$ result in hospital admissions, $48 \%$ result in outpatient visits, and $34 \%$ do not result in any medical visits (Añez et al. 2016; Shepard et al. 2016; Yuan et al. 2020).

DENVs are categorized into four distinct serotypes (DENV-1, DENV-2, DENV-3, and DENV-4), and human infection can present as undifferentiated fever, dengue fever, and dengue hemorrhagic fever (Halsey et al. 2012). Primary infection by each of the four serotypes results in long-term serotype-specific immunity and a six-month period of partial immunity to other serotypes. After this partial immunity weakens, the person becomes vulnerable to infection by the other three DENV serotypes. This secondary infection may result in the antibody-dependent enhancement/clinical manifestations (Murrell et al. 2011). 
DENV-3 is one of four DENV serotypes that have five distinct genotypes (I-V). The emergence of DENV-3 strains and lineages has been increasingly reported over time (Waman et al. 2017). DENV-3 and DENV-2 serotypes are more prevalent in countries such as Thailand, Brazil, Pakistan, and India; they are also associated with a more serious clinical profile than other serotypes (de Araujo et al. 2012; Fried et al. 2010; Mehta and Shah 2018; Yousaf et al. 2018). The reemergence of DENV-3 infections occurred Brazil in 2007, in China in 20092010, and in Gabon in 2016-2017, which can increase the risk of repeated DENV infections in a certain area (Abe et al. 2020; Liang et al. 2013; Rodriguez-Barraquer et al. 2011).

DENV encodes three structural proteins: Capsid (C), Membrane (M) or Premembrane (prM), and Envelope (E). DENV C protein is a highly simple protein with a molecular weight of $\sim 11 \mathrm{kDa}$ that is involved with RNA interaction in nucleocapsid assembly. Membrane-associated protein is a $\sim 26 \mathrm{kDa} \mathrm{M}$ glycoprotein that promotes the development of $\mathrm{E}$ protein in mature virus particles to help distinguish the immune response from different flaviviruses. The E protein is a surface protein of $\sim 55 \mathrm{kDa}$, which is a large constituent of virus particles that controls binding and fusion to the host cell membrane (Cardosa et al. 2002; Ma et al. 2004; Modis et al. 2004). The expression of prM-E or co-expression with the CprME structural proteins was an effective approach for the development of recombinant flavivirus virus-like particles (VLPs). The $\mathrm{C}$ protein can stabilize the assembly of the VLPs, although it is not necessary for particle formation (Krol et al. 2019). VLPs are selfassembled particles, which consist of viral structural proteins. They can imitate the conformation of a genuine native virus without genomic DNA or RNA, thus making them a viable option to live-attenuated vaccines (Urakami et al. 2017).

The manufacture of dengue vaccines that involve relatively small amounts of material expressed but is an extremely different type of target antigen with significant structural differences. By contrast, monoclonal antibodies share key molecular characteristics and require a production system which delivers high-performance and high-cost-efficient systems (Legastelois et al. 2017). Compare to E. coli, yeast and plant expression system, expression of Dengue structural protein in silkworm expression system will be provided with more the essential lipids, molecular chaperons, and post-translational modifications that are required for the correct membrane insertion, folding, and function of eukaryotic integral membrane proteins. Those factors will improve the forming and enhance the functionalize of the VLPs (He et al. 2014; Kato et al. 2010).
Silkworms have a strong potential for application in recombinant protein processing through the production of human proteins for therapeutic use. Moreover, silkworm expression system is easy in scale up and is possible to produce mass production without any especial equipment. Several studies support the use of insect cells in manufacturing affordable antigens and recombinant vaccines. Furthermore, insect larvae, including those from silkworms, have been used for large-scale VLP development and manufacturing (Vipin Kumar Deo 2012).

In this study, we prepared dengue virus-like particles (DENV-LPs) consisting of 3CprME and 3prME polypeptides, which were expressed using Bombyx mori nucleopolyhedrovirus (BmNPV) bacmid in silkworms. We observed the formation of VLPs and used a mouse model to verify antibody production.

\section{Materials and methods}

\section{Construction of recombinant BmNPVs}

In this study, we used the coding sequences for CprME and the prME polypeptide (GenBank: KU050695, Genewiz, New Jersey, USA). The anchor region of the capsid coding sequences for CprME was deleted for increased expression level and avoiding halt viral particle formation (Nasar et al. 2020). A linker sequence (GGGGSGGGGS) and PA-tag sequence (EGGVAMPGAEDDVV) were fused in the C-terminus and amplified by polymerase chain reaction (PCR) using a template (the synthetic gene described above). A set of primers (3CprME-F and 3CprME-R-EcoRI, Table 1) was used as a template for the DENV-3CprME coding sequence. The DENV-3prME primer set (3prME-F and 3prME-R-EcoRI, Table 1) was used to isolate the DENV-3prME coding sequence. The PCR protocol was as follows: initial denaturation at $98{ }^{\circ} \mathrm{C}$ for $10 \mathrm{~s} ; 35$ cycles of $98^{\circ} \mathrm{C}$ for $10 \mathrm{~s}, 55^{\circ} \mathrm{C}$ for $5 \mathrm{~s}$, and $72{ }^{\circ} \mathrm{C}$ for $20 \mathrm{~s} ; 72{ }^{\circ} \mathrm{C}$ for $3 \mathrm{~min}$ for the final extension. A thermal cycler (TaKaRa, Kyoto, Japan) was used to carry out the PCR reaction. Each construct was

\section{Table 1 Used primers}

\begin{tabular}{ll}
\hline Name & $\mathbf{5}^{\prime} \mathbf{- 3}^{\prime}$ \\
\hline 3CprME-F & TAA TGG ATC CAT GAA TAA CCA GCG CAA GAA \\
3CprME-R-ECoRI & TAA TGA ATT CTC AGA CTA CGT CGT CTT CCG C \\
3prME-F & TAA TGG ATC CAT GTT TCA TCT CAC TTC CCG TGA \\
& TGG C \\
3prME-R-ECoRI & TAA TGA ATT CTC AGA CTA CGT CGT CTT CCG CAC \\
pFastBac1-F & TAT TCC GGA TTA TTC ATA CC \\
pFastBac1-R & ACA AAT GTG GTA TGG CTG ATT \\
pUC/M13-F & CCC AGT CAC GAC GTT GTA AAA CG \\
pUC/M13-R & AGC GGA TAA CAA TTT CAC ACA GG
\end{tabular}

Underlines indicate restriction enzyme cleavage sites 
ligated into pFastbac1 (Thermo Fisher Scientific K. K., Tokyo, Japan), and the resulting vector was introduced into Escherichia coli $\mathrm{BmDH} 10 \mathrm{bac} \mathrm{CP}^{-} \mathrm{Chi}^{-}$(Motohashi et al. 2005). The recombinant products, which included the BmNPV/3CprME and BmNPV/3prME bacmids, were extracted from white colonies, respectively. Each recombinant BmNPV bacmid was mixed with chitosan (Sigma-Aldrich, Tokyo, Japan) and injected into fifth instar silkworm larvae (Ehime Sansyu, Ehime, Japan). The hemolymph was collected from the larvae at 6-7 days post-injection (dpi) and mixed with a $1 \mathrm{mM}$ solution of 1-phenyl-2-thiourea (Kato et al. 2016; Motohashi et al. 2005). The aliquots of hemolymph were kept at $-80{ }^{\circ} \mathrm{C}$ before use.

\section{Expression and purification of $3 \mathrm{CprME}$ and $3 \mathrm{prME}$ polypeptides in silkworm larvae}

Fifth instar silkworm larvae (Ehime Sansyu) were injected with hemolymph that was diluted 100-fold in phosphate-buffered saline (PBS, $137 \mathrm{mM} \mathrm{NaCl}, 2.7 \mathrm{mM}$ $\mathrm{KCl}, 8 \mathrm{mM} \mathrm{Na}_{2} \mathrm{HPO}_{4}$, and $2 \mathrm{mM} \mathrm{KH}_{2} \mathrm{PO}_{4}, \mathrm{pH} 7.4$ ), and raised on an artificial diet (Silkmate S2, Nosan Co., Yokohama, Japan). The legs of the larvae were cut to collect the hemolymph. The fat bodies were collected by dissecting the larvae; $1 \mathrm{~mL}$ of Tris-buffered saline containing $0.1 \%$ Triton X-100 (TBST) was added to every $0.1 \mathrm{~g}$ of fat body and sonicated for a total of $5 \mathrm{~min}$ at 20-s intervals, followed by a 10-s break (Vibra Cell VC 130 PB, Sonics \& Materials Inc., Newtown, USA). After sonication, the fat body suspension was centrifuged (Kubota 3700, Tokyo, Japan) for $10 \mathrm{~min}$ at $12,000 \times g, 4{ }^{\circ} \mathrm{C}$. The soluble fraction of the silkworm fat body suspension was mixed with $200-\mu \mathrm{L}$ beads tagged with anti-PA antibody (FUJIFILM Wako Pure Chemical, Osaka, Japan) at $4{ }^{\circ} \mathrm{C}$ for $2 \mathrm{~h}$. The mixed beads were collected and washed five times with four times of bead volumes of TBS buffer (20 mM Tris$\mathrm{HCl}$ and $150 \mathrm{mM} \mathrm{NaCl}$ ). The elution was performed with a $0.1 \mathrm{M}$ glycine- $\mathrm{HCl}$ solution $(\mathrm{pH} 3.0)$, and five fractions were collected to recover the PA-tagged target proteins. Amicon Ultra centrifugal filters (Merck Japan, Tokyo, Japan) were used to concentrate the evaluation by ultrafiltration. The concentrations of the eluate were measured using a BCA protein assay kit (Thermo Fisher Scientific K. K.).

The 3CprME and 3prME constructs were also expressed in Bm5 cells and silkworm pupae (Ehime Sansyu). Bm5 cells were provided by Prof. K. S. Boo (Insect Pathology Laboratory, School of Agricultural Biotechnology, Seoul National University, Seoul, South Korea).
Sf- 9 and Bm5 cells were maintained at $27{ }^{\circ} \mathrm{C}$ in Sf-900II serum-free medium (Thermo Fisher Scientific K.K.) supplemented with $1 \%$ fetal bovine serum (Thermo Fisher Scientific K.K.) and Antibiotic-Antimycotic solution (Thermo Fisher Scientific K.K.).

\section{Sodium dodecyl sulfate-polyacrylamide gel electrophoresis (SDS-PAGE) and western blot}

SDS-PAGE using $10 \%$ or $12 \%$ gels was used to separate the proteins. Western blotting was subsequently performed by blotting the separated proteins onto an Immobilon-P polyvinylidene fluoride membrane (Merck Japan) using the Mini Trans-Blot Electrophoretic Transfer Cell (Bio-Rad, Hercules, CA, USA). After blotting, the membrane was blocked in 5\% nonfat milk (FUJIFILM Wako Pure Chemical) in TBST (pH 7.6) and incubated in a rat anti-PA tag antibody (1:10,000; FUJIFILM Wako Pure Chemical). Other primary antibodies used included the anti-DENV E antibody (1:3000; GeneTex, Irvine, CA, USA) or the mouse anti-DENV prM antibody (1:3000; GeneTex). After incubating membranes with the primary antibodies and washing three times with TBST, the membranes were incubated for $1 \mathrm{~h}$ in horseradish peroxidase (HRP)-conjugated anti-rat IgG antibody $(1: 10,0000$; FUJIFILM Wako Pure Chemical). Immobilon Western Chemiluminescent HRP substrate (Merck Japan) was used for the detection of protein bands. Membranes were imaged using a Fluor-S MAX Multi-Imager (Bio-Rad).

\section{Transmission electron microscopy (TEM) and immunoelectron microscopy (IEM)}

TEM and IEM were carried out as previously described (Utomo et al. 2019) with minor modifications. The purified antigen sample was added to the $\mathrm{Cu}$-Grid transmission electron microscope (Nisshin EM Co., Ltd., Tokyo) and incubated for $30 \mathrm{~s}$ at room temperature, washed with $30 \mu \mathrm{L}$ of PBS, and incubated for $30 \mathrm{~s}$. This procedure was repeated three times. For IEM, $30 \mu \mathrm{L}$ of $2 \% \mathrm{v} / \mathrm{v}$ bovine serum albumin (BSA) was used for blocking after the distilled antigen sample was added, and the sample was subsequently washed three times with PBS. The $\mathrm{Cu}$-Grid was washed sequentially. Samples were incubated with Dengue virus anti-envelope rabbit polyclonal antibody (1:30; FUJIFILM Wako Pure Chemical) and goat antirabbit IgG conjugated to gold nanoparticles (1:50; FUJIFILM Wako Pure Chemical) for the first and secondary antibodies, respectively. The $\mathrm{Cu}-\mathrm{Grid}$ was treated with $2 \%$ phosphotungstic acid, and the samples were analyzed using the TEM apparatus. 


\section{Heparin-binding assay}

The heparin-binding assay was carried out as previously described (Utomo et al. 2019), with minor modifications. Biotin-labeled heparin (6 ng/mL; Sigma-Aldrich Japan) and heparin (1.8 ng) were immobilized onto avidincoated microplate wells (blocking-less type) (Sumitomo Bakelite, Tokyo, Japan) washed three times with PBS. We used $2 \mu \mathrm{g}$ BSA for negative control. Purified proteins (0.5, 1,5 , and $10 \mu \mathrm{g} / \mathrm{mL}$ ) were added into wells, incubated at room temperature for $1 \mathrm{~h}$, and subsequently washed with phosphate-buffered saline containing $0.1 \%$ Tween 20 (PBST). After serial washing, the rat anti-PA tag antibody (1:1000; FUJIFILM Wako Pure Chemical) and HRP-conjugated anti-rat IgG antibody (1:1000; FUJIFILM Wako Pure Chemical) were used as the primary and secondary antibodies, respectively. For detection, $100 \mu \mathrm{L}$ of substrate $\left(0.1 \mathrm{mg} / \mathrm{mL} 3.3^{\prime}, 5.5^{\prime}\right.$-tetramethylbenzidine [TMB] in $100 \mathrm{mM}$ sodium acetate $\left[\mathrm{CH}_{3} \mathrm{COONa}\right], \mathrm{pH}$ 6.0) were added to each well with $0.2 \%(\mathrm{v} / \mathrm{v})$ of $30 \%$ hydrogen peroxide. We added $50 \mu \mathrm{L}$ of $1 \mathrm{~N} \mathrm{H}_{2} \mathrm{SO}_{4}$ to each well to stop the reaction. Absorbance was measured at $450 \mathrm{~nm}$.

\section{VLP antigenicity by enzyme-linked immunosorbent assay (ELISA)}

Direct ELISA was used to detect an interaction between antigens, 3CprME, 3prME, the mock silkworm fat body (negative control), and sera. Two types of sera were used: mouse sera immunized with DENV tetravalent DNA vaccine (mice-Ab) (Putri D.H., personal communication, June 2017), and sera from dengue patients (human-Ab) [NS1(+), RT-PCR $(+)]$. The dengue patient sera were collected during a dengue community study that occurred from March 2010 until December 2011. Ethical approval was given by the Research Ethical Committee of the Faculty of Medicine, Universitas Indonesia, No. 71/PT02.FK/ ETIK/2009. RT-PCR positively confirmed the human-Ab from dengue patient sera based on the Lanciotti method (Lanciotti et al. 1992). Both of the sera originated from stocks from the Department of Microbiology, Faculty of Medicine, Universitas Indonesia.

For each diluted sample, $100 \mu \mathrm{L}$ of sample $(20 \mathrm{ng} /$ $\mathrm{mL}$ ) in coating buffer (0.05 M Carbonate-bicarbonate, $\mathrm{pH}$ 9.6), was applied to a 96-well ELISA microplate, followed by incubation at $4{ }^{\circ} \mathrm{C}$ overnight. After incubation, the coating solution was discarded, and a $100 \mu \mathrm{L}$ blocking solution (5\% skim milk in PBS) was added into each well and incubated for $1 \mathrm{~h}$ at $37^{\circ} \mathrm{C}$. The plates were then washed serially with PBST, followed by the addition of $100 \mu \mathrm{L}$ of mouse-Ab or human-Ab in PBS (1:5000). Plates were then incubated at $37{ }^{\circ} \mathrm{C}$ for $1 \mathrm{~h}$ and washed three times with wash buffer. Next, $100 \mu \mathrm{L}$ of goat anti-mouse or anti-human IgG-HRP-conjugated antibody (1:5000) was added to each well. Plates were incubated at $37^{\circ} \mathrm{C}$ for $1 \mathrm{~h}$ and washed sequentially. TMB substrate $(50 \mu \mathrm{L})$ was applied and incubated for $10 \mathrm{~min}$. We added $50 \mu \mathrm{L} 1 \mathrm{M}$ $\mathrm{H}_{2} \mathrm{SO}_{4}$ to stop the reaction. The absorbance was read at $450 \mathrm{~nm}$.

\section{Immunization of mice}

A total of 12 BALB/c mice, (4-6 weeks old) were divided into four groups: (i) negative control (immunized with PBS), (ii) immunized with 3CprME, (iii) immunized with 3prME, and (iv) immunized with Alhydrogel as an adjuvant. All mice were housed in a temperature-controlled, light-cycled room. Each mouse was immunized three times via intraperitoneal injection with $50 \mu \mathrm{g}$ purified 3CprME and 3prME proteins with Alhydrogel adjuvant within a 2 -week interval. Blood samples were collected via the tail vein after 0,16 , and 30 days. Sera were isolated and stored at $-80{ }^{\circ} \mathrm{C}$ until further analysis. All animal procedures were conducted in compliance with the established guidelines from the Animal Laboratory of Center of Pharmaceutical and Medical Technology, Agency for Technology Assessment and Application (BPPT), Indonesia. Animal experimental protocols were reviewed and approved by the Research Ethical Committee for the Faculty of Medicine, Universitas Indonesia, No. KET-476/UN2.F1/ETIK/PPM.00.02/2019.

\section{Results}

Expression of 3CprME and 3prME polypeptides in silkworm The DENV structural proteins consist of the C, prM, and $\mathrm{E}$ proteins, which are translated in the same order at the beginning of the polyprotein. The constructed BmNPV/3CprME (Fig. 1a) and /3prME (Fig. 1b) bacmids were injected into silkworm larvae, and the silkworm hemolymph and fat body were collected at $5 \mathrm{dpi}$. Expressions of 3CprME and 3prME were confirmed in fat body samples, and their molecular weights were 85 and $75 \mathrm{kDa}$, respectively. These molecular weights corresponded to the estimated protein sizes (Fig. 2a). Furthermore, both constructs were expressed in silkworm pupae (Fig. 2b) and Bm5 cells (Fig. 2c). Anti-DENV-2 prM and anti-DENV-2 E antibodies were used to analyze the cross-reactivity of these proteins to antibodies of DENV2. The specific bands for $3 \mathrm{CprME}$ and 3prME were not detected using these antibodies (Fig. 2d). These results indicate no cross-reactivity between DENV-2 specific antibodies with both recombinant 3CprME and 3prME expressed in silkworms. 


\section{a}
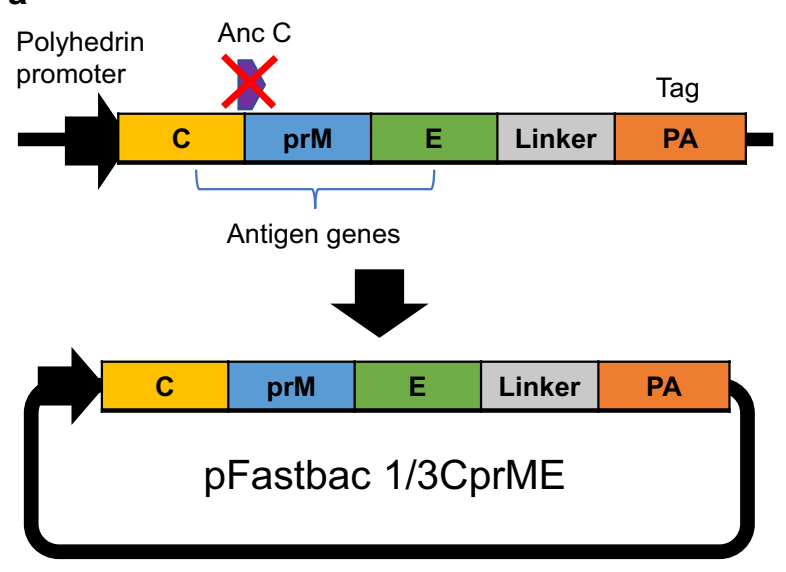

Bac to Bac

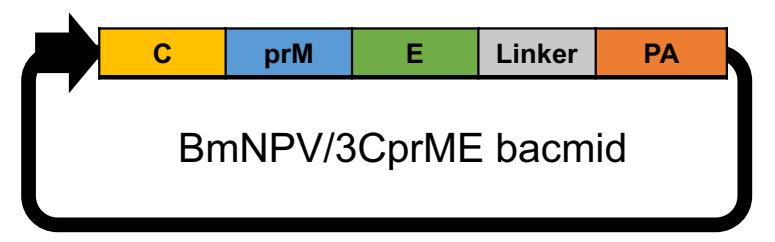

b
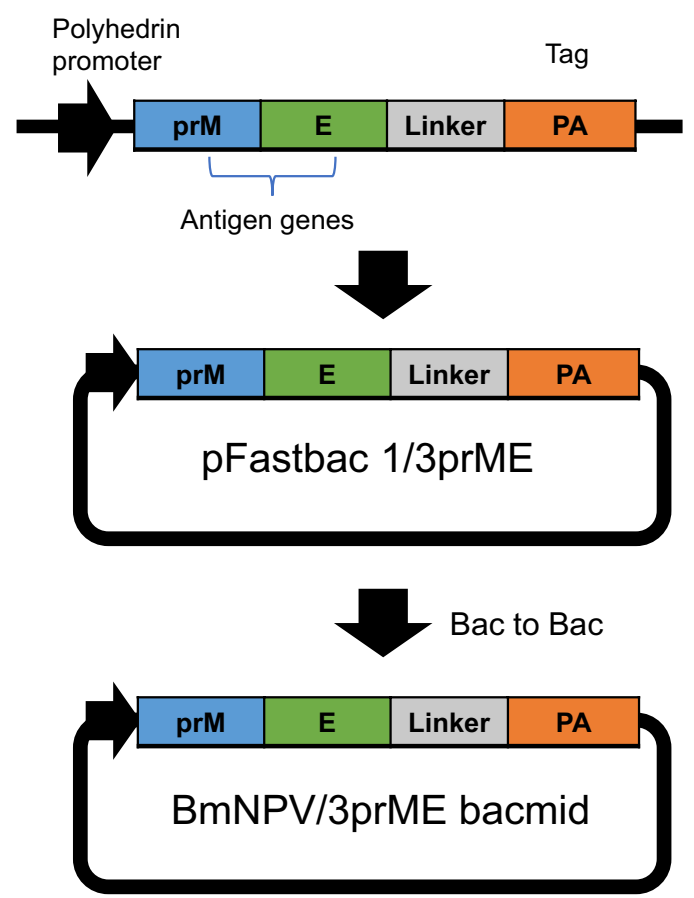

Fig. 1 Construction of recombinant dengue virus (DENV) structural proteins expressed in this study. a 3CprME with the deletion of the anchor C region and $\mathbf{b} 3$ prME polypeptides of DENV-3 were expressed in silkworms, pupae, and Bm5 cells as fusion proteins with a PA-tag

\section{Purification of 3 CprME and 3prME polypeptides}

The successful purification of the 3CprME and 3prME polypeptides using affinity chromatography was confirmed by western blot using an anti-PA-tag antibody. The imaged blot showed a band at $\sim 85 \mathrm{kDa}$ corresponding to 3CprME in elution $1-4$ and $\sim 75 \mathrm{kDa}$ for 3prME in elution 1-4 (Fig. 3a, b). To confirm whether the purified 3CprME and 3prME polypeptides contained the prM and E proteins, western blot was carried out using anti-prM or anti-E antibodies. Bands at approximately $\sim 85 \mathrm{kDa}$ and $\sim 75 \mathrm{kDa}$ were confirmed for 3CprME and 3prME, respectively (Fig. 3c, d). These results confirm that the purified 3CprME and 3prME polypeptides contained the prM and $\mathrm{E}$ proteins. The purified yield of 3CprME and 3prME was $420 \mu \mathrm{g} / 10$ silkworms and $380 \mu \mathrm{g} / 10$ silkworms, respectively. To compare the expression level, Bm5 cells, larva and pupa were compared (Additional file 1: Figure S1). Based on Additional file 1: Figure S1 result and purified result of larvae, a larva and a pupa assume to produce $42 \mu \mathrm{g}$ and $151 \mu \mathrm{g}$ of the purified $3 \mathrm{CprME}$, respectively. These results correspond to $4 \mathrm{~mL}$ and $15 \mathrm{~mL}$ of Bm5 cell culture, respectively.

\section{Morphology of the 3CprME and 3prME polypeptides}

TEM and IEM were performed to confirm the morphology of the 3CprME and 3prME polypeptides. Spherical structures with a size of 30-55 $\mathrm{nm}$ were observed (Fig. 4a, b) and it is strengthened by the data for digital light scattering (Fig. 4c, d). The IEM images revealed gold nanoparticles bonded to the surface of a lipid bilayer of spherical structured VLPs (Fig. 4e, f). The binding of gold nanoparticles on the surface of the spherical structures indicates the presence of $\mathrm{E}$ protein. These results suggest that 3 CprME and 3prME polypeptides expressed in silkworm generate DENV-3 VLPs (DENV-LP/3CprME and /3prME). 


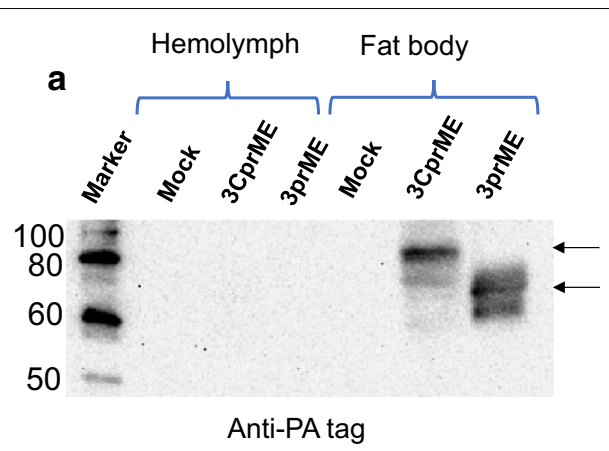

C

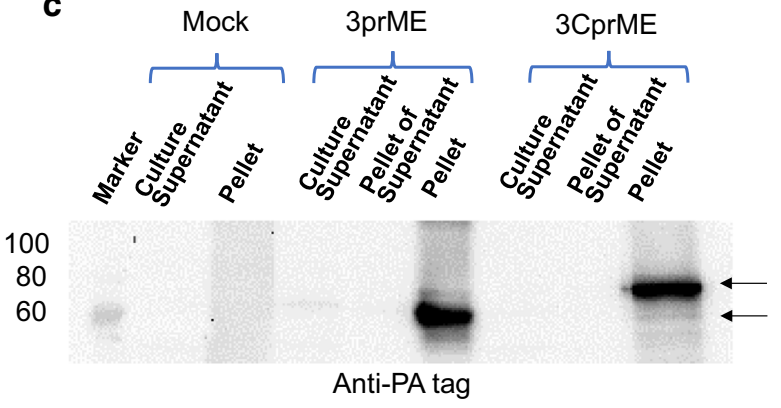

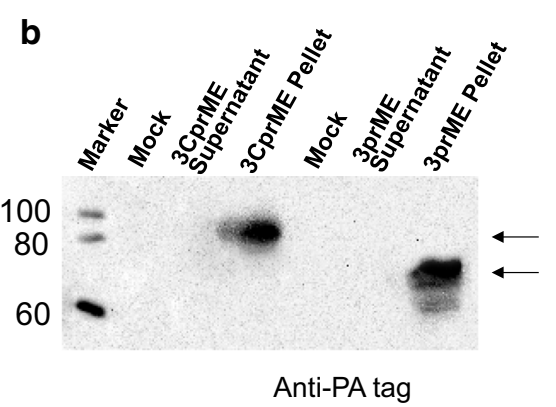

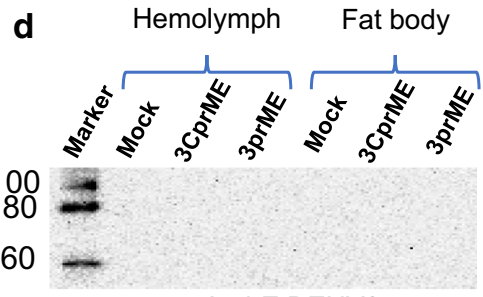

Anti-E DENV2

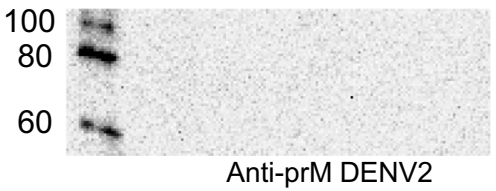

Fig. 2 Expression of 3CprME and 3prME polypeptides in silkworm larvae (a), pupae (b), and Bm5 cells (c). In the case of silkworm larvae, hemolymph, and fat body were collected after infection with recombinant BmNPV. Homogenates of each sample were prepared according to the protocol described in "Materials and methods". The 3CprME and 3prME polypeptides were detected by western blot using rat anti-PA tag as a primary antibody. $\mathbf{d}$ Hemolymph and fat body from silkworm larvae were verified for cross-reaction using mouse anti-E antibody (anti-E DENV-2) and mouse anti-prM antibody (anti-prM DENV-2) of DENV serotype 2

\section{Heparin-binding assay of the DENV-LPs/3CprME and /3prME}

The heparin-binding assay was performed to confirm the expression of E protein domain III (EDIII) on the surface of the DENV-LPs. The binding assay for the purified 3CprME and 3prME polypeptides was performed using the heparin-immobilized microtiter plates. There was a positive relationship between absorbance and the quantity of E protein compared with BSA (Fig. 5). These results suggest that the $3 \mathrm{CprME}$ and 3 prME contain the EDIII on the surface of their DENV-LPs.

\section{Antigenicity of DENV-LPs/3CprME and /3prME}

The antigenicity of purified DENV-LPs/3CprME and /3prME were characterized by direct ELISA. Our results showed that 3 CprME and 3prME showed greater reactivity to mouse-Ab and human-Ab compared with the negative control (Fig. 6a). This result indicates that
DENV-LPs/3CprME and /3prME may be used to discriminate against sera from DENV-3-infected humans.

\section{DENV-LPs/3CprME and /3prME elicited viral-specific IgG}

$\mathrm{BALB} / \mathrm{c}$ mice were immunized intraperitoneally three times at three-week intervals with $50 \mu \mathrm{g}$ of DENVLPs/3CprME and /3prME with an Alhydrogel adjuvant. The antibody titers were measured in mouse sera by ELISA at two weeks after the last immunization. Immunization with DENV-LPs/3CprME and /3prME induced the generation of anti-3CprME and anti-3prME Abs, which were analyzed for specific binding using their own antigens and reciprocal. Both specific antibodies showed a low affinity for the DENV-LPs/3CprME (Fig. 6b). On the contrary, the anti-3CprME Abs and anti-3prME Abs recognize the DENV-LPs/3prME (Fig. 6c). These results indicate that the DENV-LPs/3prME is suitable to elicit the generation of specific antibodies. 

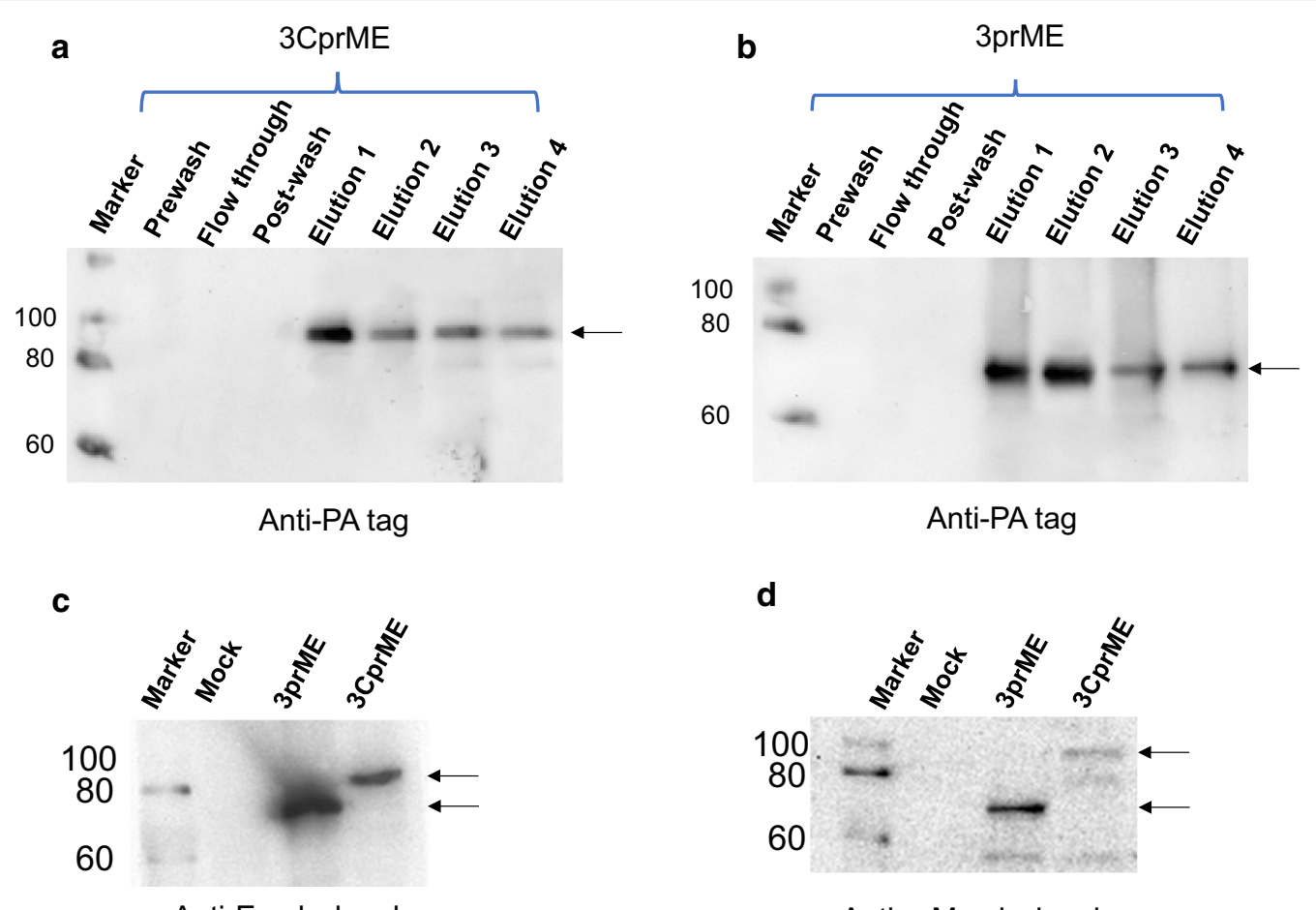

Anti-E polyclonal

Anti-prM polyclonal

Fig. 3 Western blot of purified 3CprME (a) and 3prME (b) polypeptides. Each protein was purified from silkworm larvae fat body using PA-tagged protein purification gel column chromatography. The $\mathrm{E}$ and prM were verified using rabbit anti-E protein polyclonal (c) and rabbit anti-prM protein polyclonal (d) antibodies

\section{Discussion}

Our previous study showed that the DENV-LP serotype 2 was expressed in the hemolymph of silkworm larvae (Utomo et al. 2019). In this study, the DENV-3 structural proteins 3CprME were expressed by removing the anchor sequence of capsid protein between the $\mathrm{C}$ and prM polypeptides. The purpose of the anchor capsid deletion was to increase protein expression; however, the protein cannot be released into the hemolymph of the silkworm without the anchor sequence. The expressed 3CprME and 3prME polypeptides were detected in the fat body soluble fraction, not the hemolymph.

Recombinant flaviviral VLPs can be efficiently generated with or without the $\mathrm{C}$ protein by expressing proteins prM and $\mathrm{E}$ (Sangiambut et al. 2013). The absence of prM and/or C did not affect the self-assembly of the E in VLP formation (Chang et al. 2001; Mani et al. 2013; Putnak et al. 2003). As indicated by heparin-binding assay results, EDIII was present on the surface of the VLPs because heparin in the cell membrane is known to interact with EDIII, the putative receptor-binding domain in the flavivirus $E$ protein crystal structure. EDIII also contains epitopes that block viral adsorption and is targeted by many antibodies, including serotypespecific neutralizing monoclonal antibodies (Chen et al. 2016; Frei et al. 2018; Han et al. 2018; Hidari et al. 2013; Yang et al. 2016). With the EDIII present on the surface of the VLPs, the mediated antibody is expected to have increased viral neutralization activity, which may allow it to reduce the viral load in normal DENV infection. A neutralization assay is recommended for further study.

Both 3 CprME and 3prME also showed reactivity to the mouse- $\mathrm{Ab}$ and human- $\mathrm{Ab}$; however, the human- $\mathrm{Ab}$ showed a higher affinity in the direct ELISA than the mouse-Ab. Since the mouse-Ab was obtained from mice that were immunized with the tetravalent DNA vaccine, it had lower immunogenicity compared with the human$\mathrm{Ab}$ that was isolated from DENV-infected patients. Mixed sera of dengue patients can react to many nonspecific DENV epitopes. The DENV tetravalent DNA vaccine is well tolerated and capable of generating a 

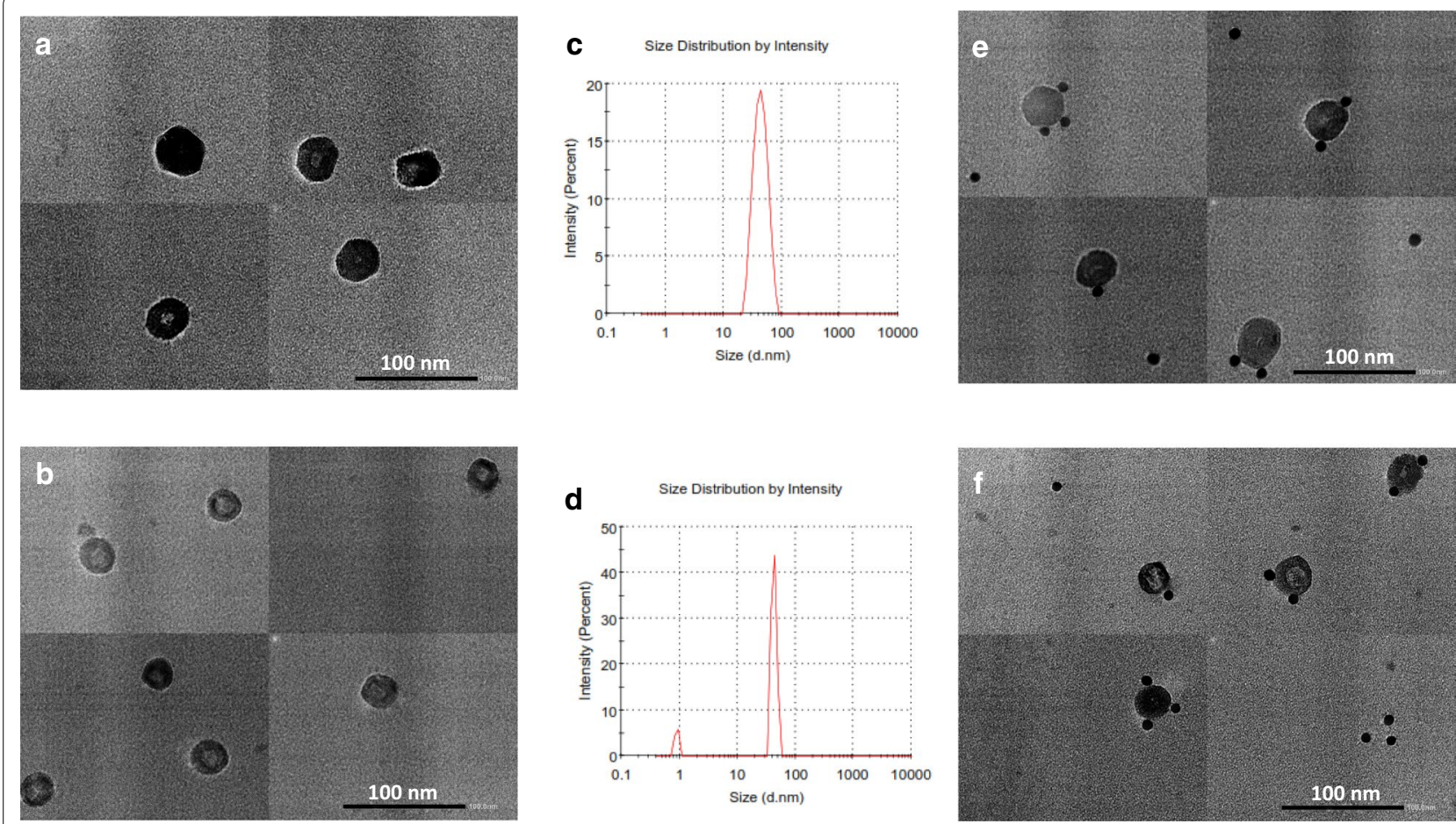

Fig. 4 TEM analysis of purified 3CprME (a) and 3prME (b) polypeptides. The purified 3CprME (c) and 3prME (d) polypeptides were immunogold-labeled using an anti-E polyclonal antibody and analyzed via IEM. Black spots in $\mathbf{c}$ and $\mathbf{d}$ indicate immunogold particles. Dynamic light scattering (DLS) was used to analyze the size distribution for 3CprME (e) and 3prME (f) polypeptides

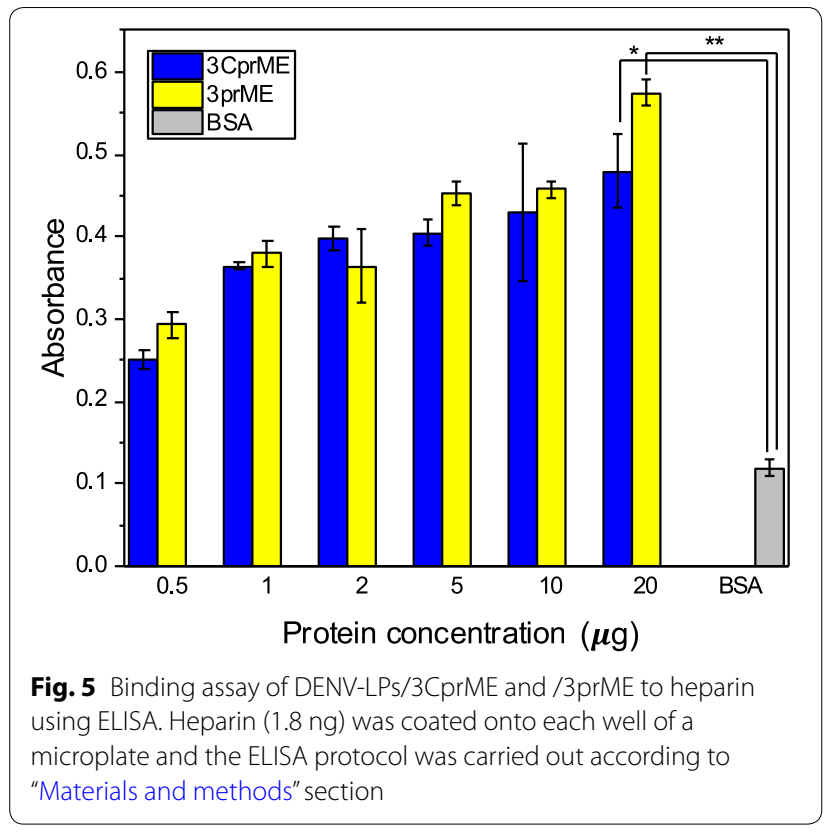

sufficient anti-dengue interferon-gamma-mediated T-cell response (Danko et al. 2018).

The DENV-LPs/3CprME and /3prME were capable of generating IgG antibodies, but the addition of the Alhydrogel adjuvant did not yield any specific binding. The detected IgG total responses in mice immunized with the 3prME showed a better profile than those immunized with 3 CprME. These differences in the response to the antigens might be caused by the deletion of the anchor domain in the $\mathrm{C}$ region, which may lower its antibody response, even though the capsid protein is not exposed on the viral surface. Each DENV serotype carries the conserved antibody epitope that is incorporated into the $\mathrm{N}$ - and $\mathrm{C}$-terminal regions of the $\mathrm{C}$ protein, which is efficiently recognized by dengue patients previously exposed to primary and secondary infections from other serotypes. The C-protein central region has an epitope of the peptide, which is primarily targeted by serotype-specific antibodies (Alves et al. 2016; Nadugala et al. 2017; Rana et al. 2018). Further analysis of the antibody response to other serotypes of 


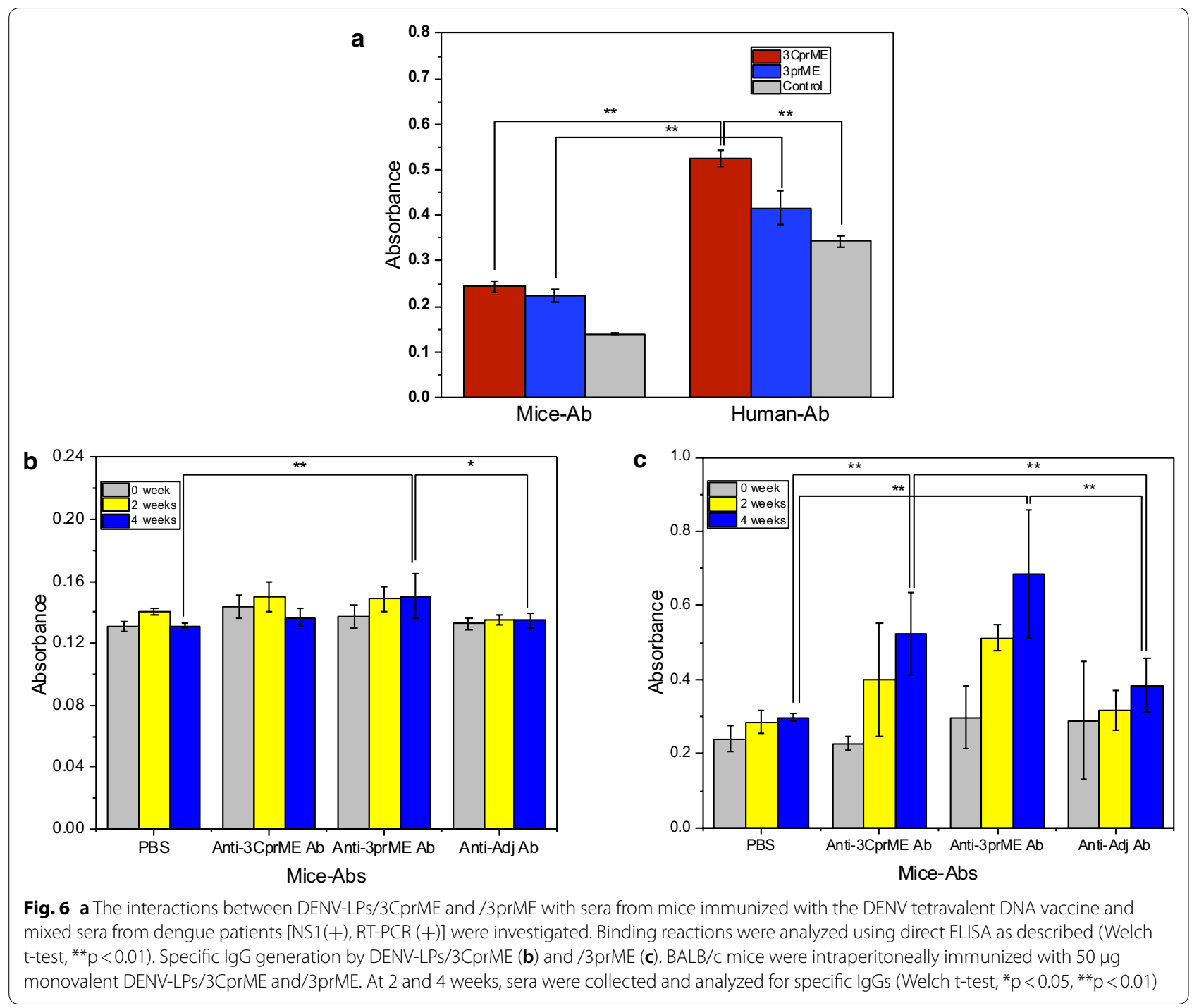

the structural proteins and the different DENV serotypes are recommended.

\section{Supplementary information}

Supplementary information accompanies this paper at https://doi. org/10.1186/s13568-020-01087-3.

Additional file 1: Figure S1. Protein expression yield of 3CprME and 3prME polypeptides in BM5 cells, silkworm larvae, silkworm pupae.

\section{Abbreviations}

Ab: Antibody; C: Capsid protein; DENV: Dengue virus; DLS: Digital light scattering; E: Envelope protein; ELISA: Enzyme-linked immunosorbent assay; EDIII: Envelope protein domain III; HRP: Horseradish peroxidase; IEM: Immunoelectron microscopy; M: Membrane protein; PBS: Phosphate-buffered saline; PBST: Phosphate-buffered saline containing 0.1\% Tween 20; PCR: Polymerase chain reaction; prM: Premembrane protein; TBS: Tris-buffered saline; TBST:

Tris-buffered saline containing $0.1 \%$ Triton X-100; TEM: Transmission electron microscopy; TMB: 3.3',5.5'-Tetramethylbenzidine; VLP: Viral-like particle; WHO: World Health Organization.

\section{Acknowledgements}

We would like to thank the staff and management of the Research Ethical Committee of the Faculty of Medicine, Universitas Indonesia, and the Animal Laboratory of Center of Pharmaceutical and Medical Technology, Agency for Technology Assessment and Application (BPPT), Indonesia.

\section{Authors' contributions}

DISU was the main researcher for this study and was involved with the experimental design and operation. SP and FS participated in animal experiments and provided resources, respectively. TK polished the language for the manuscript. EYP provided ideas, funded the research, revised the manuscript, and supervised this study. All authors read and approved the manuscript.

\section{Funding}

This work was funded by the JSPS KAKENHI (Grant-in-Aid for Exploratory Research, Grant No. 16K14900) and partly by the Heiwa Nakajima Foundation's Asian region priority academic research grant. 


\section{Availability of data and materials}

All the data and materials have been provided in the main manuscript.

\section{Ethics approval and consent to participate}

The Research Ethical Committee of the Faculty of Medicine, Universitas Indonesia approved the collection of sera from dengue patients (humanAb) $[\operatorname{NS} 1(+), R T-P C R(+)]$. Sera were collected during a dengue community study that occurred from March 2010 until December 2011 (No. 71/PT02.FK ETIK/2009). Animal experimental protocols were reviewed and approved by the Research Ethical Committee of the Faculty of Medicine, Universitas Indonesia (No. KET-476/UN2.F1/ETIK/PPM.00.02/2019). All applicable international, national, and/or institutional guidelines for the care and use of animals were followed.

\section{Consent for publication}

Not applicable.

\section{Competing interests}

The authors declare that they have no competing interests.

\begin{abstract}
Author details
1 Laboratory of Biotechnology, Graduate School of Science and Technology, Shizuoka University, 836 Ohya, Suruga-ku, Shizuoka 422-8529, Japan. ${ }^{2}$ Center of Pharmaceutical and Medical Technology, Agency for the Assessment and Application of Technology (BPPT), Jl. Kawasan Puspiptek, Gedung I LAPTIAB, Kota Tangerang Selatan, Banten 15314, Indonesia. ${ }^{3}$ Department of Microbiology, Faculty of Medicine, Universitas Indonesia, Jl.Pegangsaan Timur 16, Cikini, Jakarta 10320, Indonesia. ${ }^{4}$ Laboratory of Biotechnology, Research Institute of Green Science and Technology, Shizuoka University, 836 Ohya, Suruga-ku, Shizuoka 422-8529, Japan.
\end{abstract}

Received: 15 June 2020 Accepted: 11 August 2020

Published online: 17 August 2020

\section{References}

Abe H, Ushijima Y, Loembe MM, Bikangui R, Nguema-Ondo G, Mpingabo PI, Zadeh VR, Pemba CM, Kurosaki Y, Igasaki Y, de Vries SG, Grobusch MP, Agnandji ST, Lell B, Yasuda J (2020) Re-emergence of dengue virus serotype 3 infections in Gabon in 2016-2017, and evidence for the risk of repeated dengue virus infections. Int J Infect Dis 91:129-136. https://doi. org/10.1016/j.jijid.2019.12.002

Alves R, Pereira LR, Fabris DLN, Salvador FS, Santos RA, Zanotto PMA, Romano CM, Amorim JH, Ferreira LCS (2016) Production of a recombinant dengue virus 2 NS5 protein and potential use as a vaccine antigen. Clin Vaccine Immunol 23(6):460-469. https://doi.org/10.1128/ CVI.00081-16

Añez G, Heisey DA, Volkova E, Rios M (2016) Complete genome sequences of dengue virus type 1 to 4 strains used for the development of CBER/ FDA RNA reference reagents and WHO international standard candidates for nucleic acid testing. Genome Announc 4(1):e01583-e1615. https://doi.org/10.1128/genomeA.01583-15

Cardosa MJ, Wang SM, Sum MSH, Tio PH (2002) Antibodies against prM protein distinguish between previous infection with dengue and Japanese encephalitis viruses. BMC Microbiol 2:9. https://doi. org/10.1186/1471-2180-2-9

Chang G-JJ, Davis BS, Hunt AR, Holmes DA, Kuno G (2001) Flavivirus DNA vaccines. Ann N Y Acad Sci 951(1):272-285. https://doi. org/10.1111/j.1749-6632.2001.tb02703.x

Chen J, Wen K, Li XQ, Yi HS, Ding XX, Huang YF, Pan YX, Hu DM, Di B, Che XY, Fu N (2016) Functional properties of DENV EDIII-reactive antibodies in human DENV-1-infected sera and rabbit antiserum to EDIII. Mol Med Rep 14(2):1799-1808. https://doi.org/10.3892/mmr.2016.5454

Danko JR, Kochel T, Teneza-Mora N, Luke TC, Raviprakash K, Sun P, Simmons M, Moon JE, De La Barrera R, Martinez LJ, Thomas SJ, Kenney RT, Smith $L$, Porter KR (2018) Safety and immunogenicity of a tetravalent dengue DNA vaccine administered with a cationic lipid-based adjuvant in a phase 1 clinical trial. Am J Trop Med Hyg 98(3):849-856. https://doi. org/10.4269/ajtmh.17-0416
De Araujo JM, Bello G, Romero H, Nogueira RM (2012) Origin and evolution of dengue virus type 3 in Brazil. PLoS Negl Trop Dis 6(9):e1784. https:// doi.org/10.1371/journal.pntd.0001784

Frei JC, Wirchnianski AS, Govero J, Vergnolle O, Dowd KA, Pierson TC, Kielian M, Girvin ME, Diamond MS, Lai JR (2018) Engineered dengue virus domain III proteins elicit cross-neutralizing antibody responses in mice. J Virol 92(18):e01023-e1118. https://doi.org/10.1128/JVI.01023-18

Fried JR, Gibbons RV, Kalayanarooj S, Thomas SJ, Srikiatkhachorn A, Yoon IK, Jarman RG, Green S, Rothman AL, Cummings DA (2010) Serotype-specific differences in the risk of dengue hemorrhagic fever: an analysis of data collected in Bangkok, Thailand from 1994 to 2006. PLoS Negl Trop Dis 4(3):e617. https://doi.org/10.1371/journal.pntd.0000617

Halsey ES, Marks MA, Gotuzzo E, Fiestas V, Suarez L, Vargas J, Aguayo N, Madrid C, Vimos C, Kochel TJ, Laguna-Torres VA (2012) Correlation of serotype-specific dengue virus infection with clinical manifestations. PLoS Negl Trop Dis 6(5):e1638. https://doi.org/10.1371/journ al.pntd.0001638

Han S-C, Huy N-X, Kim M-Y (2018) Enhanced expression of dengue virus EDIII-based tetravalent antigen protein using transgenic rice callus. Plant Biotechnol Rep 12(3):207-215. https://doi.org/10.1007/s1181 6-018-0487-6

He Y, Wang K, Yan N (2014) The recombinant expression systems for structure determination of eukaryotic membrane proteins. Protein Cell 5(9):658-672. https://doi.org/10.1007/s13238-014-0086-4

Hidari Kl, Abe T, Suzuki T (2013) Carbohydrate-related inhibitors of dengue virus entry. Viruses 5(2):605-618. https://doi.org/10.3390/v5020605

Kato T, Kajikawa M, Maenaka K, Park EY (2010) Silkworm expression system as a platform technology in life science. Appl Microbiol Biotechnol 85(3):459-470. https://doi.org/10.1007/s00253-009-2267-2

Kato T, Arai S, Ichikawa H, Park EY (2016) Versatility of chitosan/BmNPV bacmid DNA nanocomplex as transfection reagent of recombinant protein expression in silkworm larvae. Biotechnol Lett 38(9):1449-1457. https ://doi.org/10.1007/s10529-016-2144-x

Krol E, Brzuska G, Szewczyk B (2019) Production and biomedical application of flavivirus-like particles. Trends Biotechnol 37(11):1202-1216. https:// doi.org/10.1016/j.tibtech.2019.03.013

Lanciotti RS, Calisher CH, Gubler DJ, Chang GJ, Vorndam AV (1992) Rapid detection and typing of dengue viruses from clinical samples by using reverse transcriptase-polymerase chain reaction. J Clin Microbiol 30(3):545-551

Legastelois I, Buffin S, Peubez I, Mignon C, Sodoyer R, Werle B (2017) Non-conventional expression systems for the production of vaccine proteins and immunotherapeutic molecules. Human Vaccines Immunother 13(4):947-961. https://doi.org/10.1080/21645515.2016.1260795

Liang H, Luo L, Yang Z, Di B, Bai Z, He P, Jing Q, Zheng X (2013) Re-emergence of dengue virus type 3 in Canton, China, 2009-2010, associated with multiple introductions through different geographical routes. PLoS ONE 8(2):e55353. https://doi.org/10.1371/journal.pone.0055353

Ma L, Jones CT, Groesch TD, Kuhn RJ, Post CB (2004) Solution structure of dengue virus capsid protein reveals another fold. Proc Natl Acad Sci USA 101(10):3414-3419. https://doi.org/10.1073/pnas.0305892101

Mani S, Tripathi L, Raut R, Tyagi P, Arora U, Barman T, Sood R, Galav A, Wahala W, de Silva A, Swaminathan S, Khanna N (2013) Pichia pastorisexpressed dengue 2 envelope forms virus-like particles without premembrane protein and induces high titer neutralizing antibodies. PLoS ONE 8(5):e64595. https://doi.org/10.1371/journal.pone.0064595

Mehta T, Shah P (2018) Identification of prevalent dengue serotypes by reverse transcriptase polymerase chain reaction and correlation with severity of dengue as per the recent World Health Organization classification (2009). Ind J Med Microbiol 36(2):273-278. https://doi. org/10.4103/ijmm.IJMM_17_427

Modis Y, Ogata S, Clements D, Harrison SC (2004) Structure of the dengue virus envelope protein after membrane fusion. Nature 427(6972):313319. https://doi.org/10.1038/nature02165

Motohashi T, Shimojima T, Fukagawa T, Maenaka K, Park EY (2005) Efficient large-scale protein production of larvae and pupae of silkworm by Bombyx mori nuclear polyhedrosis virus bacmid system. Biochem Biophys Res Commun 326(3):564-569. https://doi.org/10.1016/j. bbrc.2004.11.060 
Murrell S, Wu SC, Butler M (2011) Review of dengue virus and the development of a vaccine. Biotechnol Adv 29(2):239-247. https://doi. org/10.1016/j.biotechadv.2010.11.008

Nadugala MN, Jeewandara C, Malavige GN, Premaratne PH, Goonasekara CL (2017) Natural antibody responses to the capsid protein in sera of dengue infected patients from Sri Lanka. PLoS ONE 12(6):e0178009. https://doi.org/10.1371/journal.pone.0178009

Nasar S, Rashid N, Iftikhar S (2020) Dengue proteins with their role in pathogenesis, and strategies for developing an effective anti-dengue treatment: a review. J Med Virol 92(8):941-955. https://doi.org/10.1002/ jmv.25646

Putnak R, Porter K, Schmaljohn C (2003) DNA vaccines for flaviviruses advances in virus research. Adv Virus Res 61:445-468

Rana J, Slon Campos JL, Leccese G, Francolini M, Bestagno M, Poggianella M, Burrone OR (2018) Role of capsid anchor in the morphogenesis of zika virus. J Virol 92(22):e01174-e1218. https://doi.org/10.1128/JVI.01174-18

Rodriguez-Barraquer I, Cordeiro MT, Braga C, de Souza WV, Marques ET, Cummings DA (2011) From re-emergence to hyperendemicity: the natural history of the dengue epidemic in Brazil. PLoS Negl Trop Dis 5(1):e935. https://doi.org/10.1371/journal.pntd.0000935

Sangiambut S, Suphatrakul A, Sriburi R, Keelapang P, Puttikhunt C, Kasinrerk W, Malasit P, Sittisombut N (2013) Sustained replication of dengue pseudoinfectious virus lacking the capsid gene by trans-complementation in capsid-producing mosquito cells. Virus Res 174(1-2):37-46. https://doi.org/10.1016/j.virusres.2013.02.009

Shepard DS, Undurraga EA, Halasa YA, Stanaway JD (2016) The global economic burden of dengue: a systematic analysis. Lancet Infect Dis 16(8):935-941. https://doi.org/10.1016/S1473-3099(16)00146-8

Urakami A, Ngwe Tun MM, Moi ML, Sakurai A, Ishikawa M, Kuno S, Ueno R, Morita K, Akahata W (2017) An envelope-modified tetravalent dengue virus-like-particle vaccine has implications for flavivirus vaccine design. J Virol 91(23):e01181-e1217. https://doi.org/10.1128/JVI.01181-17

Utomo DIS, Hirono I, Kato T, Park EY (2019) Formation of virus-like particles of the dengue virus serotype 2 expressed in silkworm larvae. Mol Biotechnol 61(11):852-859. https://doi.org/10.1007/s12033-019-00210-5

Vipin Kumar Deo TK (2012) Functional virus-like particles production using silkworm and their application in life science. J Biotechnol Biomater s9(01):S9. https://doi.org/10.4172/2155-952x.S9-001

Waman VP, Kale MM, Kulkarni-Kale U (2017) Genetic diversity and evolution of dengue virus serotype 3: a comparative genomics study. Infect Genet Evol 49:234-240. https://doi.org/10.1016/j.meegid.2017.01.022

Yang J, Zou L, Yang Y, Yuan J, Hu Z, Liu H, Peng H, Shang W, Zhang X, Zhu J, Rao X (2016) Superficial vimentin mediates DENV-2 infection of vascular endothelial cells. Sci Rep 6:38372. https://doi.org/10.1038/ srep38372

Yousaf M, Junaid K, Iqbal MS, Aslam I, Ahmad S, Aqeel M, Ashfaq UA, Khaliq S, Ghani MU, Waqar N (2018) Analysis of dengue virus burden and serotypes pattern in Faisalabad, 2016-2017. Future Virol 13(4):245-251. https://doi.org/10.2217/fvl-2017-0155

Yuan HY, Liang J, Lin PS, Sucipto K, Tsegaye MM, Wen TH, Pfeiffer S, Pfeiffer D (2020) The effects of seasonal climate variability on dengue annual incidence in Hong Kong: a modelling study. Sci Rep 10(1):4297. https://doi. org/10.1038/s41598-020-60309-7

\section{Publisher's Note}

Springer Nature remains neutral with regard to jurisdictional claims in published maps and institutional affiliations.

\section{Submit your manuscript to a SpringerOpen ${ }^{\odot}$ journal and benefit from:}

- Convenient online submission

- Rigorous peer review

- Open access: articles freely available online

- High visibility within the field

- Retaining the copyright to your article

Submit your next manuscript at $\boldsymbol{\nabla}$ springeropen.com 